\title{
A kutatómunka jelentősége a szociális munka hivatássá válásában
}

\section{The role of scientific research in the professionalization of social work}

\section{B. ERDÖS MÁRTA}

B. Erdős Márta: Pécsi Tudományegyetem, Bölcsészettudományi Kar, Társadalmi Kapcsolatok Intézete, Közösségi és Szociális Tanulmányok Tanszék; erdos.marta@pte.hu

Márta B. Erdös: University of Pécs, Faculty of Humanities, Institute of Social Relations, Department of Community and Social Studies; erdos.marta@pte.hu

\begin{abstract}
Absztrakt
A tanulmány - a hazai hagyományoktól eltérően - a szociálismunka-kutatást mint a társadalomtudományi kutatások átfogó területén belüli önálló, sajátos kérdésekkel, kérdésfeltevéssel és módszertannal jellemezhető területet határozza meg. Áttekinti a szociálismunka-kutatások fejlődését az Amerikai Egyesült Államokban, és ennek alapján vázolja fel a lehetséges irányokat. Rávilágít a szociálismunka-kutatások szerepére a praxis fejlesztésében, valamint a szakterület hivatássá válásában.
\end{abstract}

Kulcsszavak: szociálismunka-kutatás, professzionalizáció, történeti összehasonlítás, kritikaireflektív gyakorlat

\begin{abstract}
The article interprets social work research as a distinct field, characterized by specific questions, appraoches and methodologies within the broad area of social research - this differentiation is new in Hungary. Reviewing the development of social work research, the author outlines possible developmenal directions; and comments on the role of social work research in the development of social work practice and professionalization.
\end{abstract}

Keywords: social work research, professionalization, comprative-historical approach, criticalreflective practice

„A szakma egyik legnagyobb kihívása, hogy miképpen integráljuk a szenvedélyes, cselekvésorientált reformer és az odaadó konzulens szerepkörét; valamint a minden szociális munkásban jelenlévö (objektív) tudományos megfigyelöt a szakmai közösségbe." (Maschi és mtsai., 2012: 4) 


\section{Bevezető gondolatok}

A szociális munka területének megerősítésére napjainkban nagy szükség van, hiszen a praxis felől óriási a nyomás a magasan képzett, minőségi és hatékony munkát végző szakemberek kibocsátására. Ez hosszú távon segíthetne abban is, hogy a hazai társadalom érzékenyebben, szolidárisabban válaszoljon az egyre mélyülő szociális problémákra. E fejlesztési cél sokféle módon és számos eszközzel közelíthető meg. A sok lehetséges kérdés, nézőpont közül ennek az írásnak a fókuszában most az áll, hogy miképpen segítheti a kutatómunka a szociális hivatás további fejlődését.

Mit jelent pontosan a szociálismunka-kutatás? A szociális munka területén - ahogyan erre Beckerman már 1978-ban rámutatott - a kutatások eredményei gyakran azért nem tudnak hasznosulni, mert ezeket egy eltérő, jóval általánosabb paradigma, a társadalomtudományi kutatások nézőpontja szerint végzik, nem pedig a szociálismunka-kutatások prioritásait szem előtt tartva. A különbségtétel nem egyszerü, hiszen a két területet a wittgensteini családhasonlóság köti össze, azaz vannak eltérések, de bőven vannak rokon vonások is. Társadalomtudományi kutatás alatt ma Magyarországon gyakran csak azt értjük, amivel a szociológusok foglalkoznak. A szociológiai kutatások célja többnyire a makroszintü társadalmi kérdések vizsgálata, így sokszor nagy mintákkal dolgoznak, és nem kerülnek közeli, intenzív kapcsolatba a kutatás alanyaival. A kutatás során az eredmények hasznosíthatósága is inkább csak közvetett kérdésként merül fel. A szociálismunka-kutatás ezzel szemben elválaszthatatlan a szociális munka problématerületeitől, a problémamegoldó folyamatoktól, az értékeléstől, és a szociális programok, szolgáltatások fejlesztésétől. Ahogyan maga a terület is transzdiszciplináris, azaz a problémamegoldás érdekében egységbe olvaszt különböző elméleti területeket, sőt a módszereket, a gyakorlatot is, úgy a szociálismunka-kutatás is transzdiszciplináris, mind szemléletében, mind pedig módszereiben. A makroszintű társadalmi változások értelmezésének készségén túl az eltérő kultúrák, a kommunikációs mintázatok és szokások, a közösségi-családi kapcsolatok, a személyes életút vizsgálata komoly kutatói felkészültségeket és ráfordításokat, időt és energiát követel meg, amelyekért azonban bőven kárpótolja a kutató szociális munkást az otthonosság élménye. Ezek a kutatások ugyanis már arról a világról szólnak, amelyben élünk és dolgozunk, azokról a nehézségekről és eredményekről, amikkel mi magunk is nap mint nap találkozunk. Így a kutatás valóban a praxist fogja segíteni, és ez az új tapasztalat elvezethet a két terület - praxis és kutatás jelenleginél sokkal szorosabb kapcsolatához.

\section{Történeti áttekintés - az amerikai modell tanulságai}

A szociális munka mint tudományterület története az Amerikai Egyesült Államokban azzal kezdődött, hogy elkezdték vizsgálni, milyen módon lehetne javítani a rászoruló, tarthatatlan élethelyzetben megrekedt csoportok - így például a szegények, a bántalmazott gyermekek, a hajléktalanok, a bevándorlók, menekültek, fogvatartottak, pszichiátriai betegek helyzetén, életminőségén. A kutatás és a szakma gyakorlása szervesen kapcsolódott egymáshoz. A vizsgálatokban etnográfiai és szociológiai módszereket alkalmaztak, mégpedig nagyon gyakorlatias célokat követve, a jólét és jóllét kiterjesztése, a társadalmi igazságosság gyakorlatának megerősítése érdekében.

1841-ben az amerikai szociális munkát erősen befolyásoló Dorothea Dix kutatásokat folytatott és javaslatokat tett az elzárt pszichiátriai betegek helyzetének javítására (Greif, Chaiklin \& Timlin, 2010). 1865-ben, a „tudományos filantrópia” meghaladásával megalakult a 
kor tudományos követelményeinek megfelelő American Social Science Association, az 1880as években pedig elindulnak a settlement mozgalmak, az angliai Toynbee Hall (1884) mintájára 1889-ben az amerikai Hull House. 1890-ben egy ma is korszerünek és izgalmasnak számító kvalitatív kutatást folytatott le Jacob Riis, aki fotódokumentációs felmérést végzett a szegénységröl (Maschi és mtsai., 2012).

Az orvos Flexner 1915-ben teszi fel provokatív, egyben azonban nagyon is inspirálónak bizonyuló kérdését: hivatás-e a szociális munka, amelynek lényegében nincs önálló módszertana? Erre a kérdésre az adott kontextusban Mary Richmond szociális diagnózisa lesz a legerősebb válasz (Blundo, 2006). A társadalmi igazságosság képviselete mellett útjára indul a „professzionalizáció projektje”. Az e program körül kialakuló szakmai viták lényegében máig tartanak (Olson, 2007; Weiss-Gal \& Welbourne, 2008). Hazai környezetben sem könnyü a két projekt integrálása, amelynek dilemmáit Margolin (1997, id. Olson, 2007) igen találóan foglalja össze: „Addamset prédikálnak, de Richmondból merítenek” (Olson, 2007: 60).

A pragmatista amerikai színtéren viszonylag hamar, az 1900-as évek elejére elérkezünk oda, hogy a szociális munka oktatása markánsan elkülönül a valamivel hosszabb múltra visszatekintő társterületektől, a szociológiától és a pszichológiától. 1919-ben megalakul a School of Social Work, a szakma fejlödésében, az oktatásban kulcsszerepet játszó Council of Social Work Education elődje (Maschi és mtsai., 2012).

Az oktatás mellett az Amerikai Egyesült Államokban a harmincas években már nagyon határozott profilt ölt a szociálismunka-kutatások világa. Az 1930-31-ben megrendezett konferencián (Conference of Social Work) Cabot a praxist értékelő kutatások szükségessége mellett érvel; Abbott pedig specifikus tudományos módszerek igényével lép fel. 1937-ben megtörténik az első hivatalos különbségtétel a társadalomtudományi kutatás (social research) és az ezen belül már más prioritások szerint szerveződő, eltérő fókuszú, ennek megfelelően módszertanában is specifikus szociálismunka-kutatás (social work research) között (Maschi és mtsai., 2012). Ez a markáns, a szakterület specifikumaira érzékeny különbségtétel hazánkban szélesebb körben szinte teljesen ismeretlen, leszámítva néhány, az akadémiai környezetben megfogalmazódó kezdeményezést (Bányai, 2018; Sík \& Szécsi, 2015; Szoboszlai \& Patyán, 2016; B. Erdős \& Vojtek, 2018).

1951-re az USA-ban az ütemes fejlődés a szociálismunka-kutatások absztraktjainak indexálását hozza; az 1960-as, 1970-es években elindul a saját doktori képzés, megkezdődik a szociális munka doktori programok elterjedése. Ezzel párhuzamosan egyre hangsúlyosabb kutatás és gyakorlat kapcsolata vizsgálatának igénye, valamint a praxis értékelésének igénye. 1982-ben a Council of Social Work Education Curriculum Policy Statementje fogalmazza meg határozottan a kutatás gyakorlatba integrálásának szükségességét.

Az amerikai környezetben az erős pszichológiai és szociálpszichiátriai hagyományokra építve a szakma jelentős részesedést tudhat magáénak a mentálhigiénés ellátások területén: ezeknek az ellátásoknak mintegy 80\%-át a szociális munkások végzik (Cooper \& Lesser, 2002). Így a nyolcvanas évek végén a National Institute of Mental Health - egy szakmai szempontból nagyon erős, publikációit a nemzetközi térben is könnyen elérhetővé, így magasan hivatkozottá tévő szervezet - „Building Social Work Knowledge” (kb.: A szociálismunkás-tudások felépítése) címmel folytat le nagyszabású projektet. 1994-ben létrejön a Society for Social Work Research, majd 2010-ben a Journal of Society for Social Work Research (Maschi és mtsai., 2012). 


\section{A szakma hazai fejlődésének néhány kérdése}

Hazánkban a szociális munka fejlődését súlyosan visszavetette a két világháború közvetlen pusztítása, a második világháborút megelőzően a fasizmus térhódítása, és a második világháború után kialakuló nyílt, majd puha diktatúrák destruktív ideológiai-politikai hatása. A nyílt diktatúra éveiben szociális munka - érthető okokból - nem létezhetett (Pik, 1998). A korszak központilag levezényelt ingyenmunkája, „társadalmi munkája” (melynek tükörfordítása éppen social work) az önkéntességet és a közösségekért végzett munkát máig ható, ugyanakkor torz, az akadémiai világtól távoli értelmezési keretbe helyezte.

Később, a hetvenes években megszületett a praxis egy fontos területe (a Nevelési Tanácsadókban végzett családgondozás), ám az azóta is sokat vitatott keresztelőre még várni kellett. A pályán lévő szociális munkások maguk sem tudták, hogy mi is az ő valódi foglalkozásuk - és természetesen megfelelő képzésben sem részesülhettek, inkább csak a gyakorlatban, hosszú évek alatt sajátították el a szükséges ismereteket (Talyigás \& Hegyesi, 2014; Darvas \& Hegyesi, 2003). A képzés hiánya, a szakterület körvonalazatlansága esetlegességekhez vezetett: ebben a hőskorban kitűnő szakemberek és a pályára aligha alkalmasak egyaránt müködhettek családgondozóként, kialakítva azt a képet, hogy az alkalmasság nem a képzésen, és különösen nem a kutatómunka formálta tudományos-szakmai háttéren múlik, hanem döntően személyes kvalitás és elhatározás kérdése; még rosszabb esetben a kontraszelekció eredménye. Az első diplomás szakembereket (a szociális szervezőket) végül a Bárczi Gusztáv Gyógypedagógiai Főiskolán képezték (Pik, 1998).

A puha diktatúra a lehetőségekhez képest igyekezett mérsékelni a társadalmi feszültségeket, és fellépni a gondoskodó-gyámkodó állam szerepében. A szociális problémák ugyanakkor továbbra is erősen takarásban maradtak. Amennyiben mégis tárgyalásra kerültek, annak mindig erőteljes ideológiai vonatkozásai voltak - így került például a fiatalkori problémás szerhasználat egy olyan keretezésbe, amelyből szemlélve „rendszerellenes”, sőt, egy másik, szubkulturális nézőpontból szinte forradalmi tettnek számított (Bajzáth, Tóth \& Rácz, 2014; Csapláros, 2017) maga a probléma, és annak kezelése is. Bár van ebben igazság - hiszen minden deviancia a fennálló rend motivációs bázisának tagadása, így egyfajta közvetett kritikája (Miller, 2002) - mégis, ez a fajta átkeretezés aligha volt segítségére a kor gyakorló szakembereinek, akiknek nem annyira a szerhasználóknak (általában tévesen) tulajdonított „ellenforradalmi” lendülettel akadhatott tennivalójuk, hanem inkább az egyéni-családi életút elakadásait kellett felszámolniuk. A korabeli kormányzati hozzáállás jól mutatja a szociális terület átpolitizáltságát, és ebből fakadó sebezhetőségét. Ennek az öröklött átpolitizáltságnak a magas szintű szakmaiság, az igényes, elfogulatlan kutatómunka és a tudományos gondolkodás lehet a megfelelö és szükségszerü ellenpontja.

A szegénységgel kapcsolatos első, a szociális munka fejlődését alapvetően meghatározó kutatások Ferge Zsuzsanna irányításával indulhattak el (Darvas \& Hegyesi, 2003). Szerepe volt még a szakma fejlődésében a „társadalmi beilleszkedési zavarok” (TBZ) kutatásának, ahol a központilag meghatározott kiindulópontok szerint ugyan a beilleszkedés a probléma (azaz az államszocialista érában nem a társadalmi célokat és gyakorlatokat tekintették problémásnak), ám az eredmények már egy anómiás társadalom képét rajzolták ki (ld. pl. Buda és mtsai., 1986).

A szociális munka bevezetése a rendszerváltozást követően a kádári puha diktatúra, az államszocialista rendszer megmentésének, „kijavításának” céljával történt meg (Darvas és Hegyesi, 2003). Nem sokkal ezután, 1989-ben már azzal a teljesen lehetetlen küldetéssel terhelték meg, hogy a rendszerváltozás ártalmas társadalmi hatásait kivédje (Patyán, 2015) elérhető eszközök, azaz erős intézményrendszer, megfelelően képzett és megfelelő számú 
szakember nélkül, illetve megfelelő mélységü, kiterjedésű megalapozó, és az intervenciókat rutinszerüen értékelő kutatómunka nélkül.

A szociális munkások szervezett képzése a rendszerváltozás környékén kezdődőtt meg, Flexner klasszikus kérdésének hazai megfelelöjét pedig 2009-ben hallhattuk. A flexneri kritika lényege, hogy a szakmai tevékenység alapja valamilyen, az attitüdöket meghatározó értékrend vagy ideológia, nem pedig a tudomány. Akár jogos a kritika, akár csak a szakterületet nem ismerő külső szemlélő számára tünik jogosnak, következményei nagyon is valóságosak.

Az államszocializmus éveinek tapasztalatai a kommunikatív emlékezetbe kódolódtak, és ma is meghatározzák a szociális problémák konstrukcióját, a szakterületről folytatott társadalmi diskurzust. E szerint a problémákkal való törödés, az odafigyelés és a gondoskodás az állam feladata, és senki más felelőssége, ha pedig valakiről mégsem gondoskodnak, akkor az nyilván rá is szolgált, mint az egykori „lumpenproletár” vagy a „közveszélyes munkakerülő” mai alteregója, akinek nem segítőre, hanem inkább hatósági ellenőrzésre van szüksége. Ehhez társul a közéleti diskurzus polarizáló, sarkított jellege, és tartós örökségként a puha diktatúra elkent, inkonzisztens, a józan gondolkodást és reflektivitást összezavaró jelentés-alakításának kései, de mindmáig eleven hatása (B. Erdős \& Kelemen, 2011). Hazánkban rendszerszinten az utóbbi évtizedekben nem volt, és markánsan ma sincs még jelen az a fajta, az elesettekkel szolidaritást vállaló gondolkodásmód, ami a szakma amerikai fejlődésmenetében éppen a kiindulópontot jelentette, és a szakmai fejlődést a társadalom oldaláról, és annak cselekvésben is megnyilvánuló akaratából kikényszerítette. A nyolcvanas évek végén, a kilencvenes évek elején a szociális munka új hazai hőskorában ezek a törekvések, próbálkozások a szociális munka és egyes társszakmák (pl. a közösségfejlesztés) kialakulását ugyanakkor jelentősen elősegítették (Bányai, 2018; Giczey, 2015). Megjelentek fontos közösségi kezdeményezések (pl. Nyers, 2018). Ezek a valódi, nem ,„papíralapú”, az önkéntesség keretein belül értelmezhető szolidáris cselekvések jól jelzik, hogy a hazai társadalom egyes csoportjaiban tudatosultak a megoldatlan társadalmi kérdések, és kialakult a megfelelő problémaérzékenység. E csoportok készek önmagukhoz mérten felelősséget és kezdeményező szerepet vállalni a problémák megoldásában - de nyilvánvalóan nem vállalhatják fel egy modern, a globális gazdaságban lehetősgeihez képest erős szerepet vállalni kívánó állam szociális biztonsággal, szociális védelemmel kapcsolatos alapvető feladatait (Neményi \& Csepeli, 2002). Szociálismunkakutatások, és az eredmények hasznosulása nélkül azonban nem fogunk tudni megfelelöen differenciálni a problémákra adott megfelelő, és nem adekvát szinten megfogalmazódó válaszok között.

A kutatási eredmények szakmai és nyilvánosság felé irányuló disszeminációja is nagyon fontos, mert a szakma természetes érintkezési pontjain kívül - ezek a társzakmák, a döntéshozók, a kliensek csoportjai - még ma sem kellően ismert vagy elismert a szociális munkások feladatköre, szerepe. Sőt, a társadalmi problémák kezelése során a szociális munkás is gyanússá válik, mert stigmatizált csoportokkal érintkezik. A stigma pedig ragadós (Goffman, 2009; Hobbs \& Evans, 2017). Ehhez járul még az a sajátos, politikai természetü címke, ami ebben az ízig-vérig reformszellemű és változásorientált területben az államszocializmus, a puha, de belső hamisságai, értékvesztettsége, inkonzisztenciái és kettős kötést kialakító helyzetei miatt mégiscsak destruktív kádári diktatúra fenyegető árnyait véli felfedezni. A szociális munkához való ambivalens viszonyulás, a terület időszakos fenyegetettsége vagy degradálása azonban nem kizárólagosan magyar sajátosság (ld. pl. Hobbs \& Evans, 2017). Számos más országban is éppen ez az ambivalencia indította útjára a professzionalizáció projektjét. 


\section{Professzionalizáció és kutatómunka}

A professzionalizáció, azaz adott tevékenységcsoport hivatássá válásának előrehaladását ma két, egymással összefüggő szempontrendszer szerint ítélhetjük meg. Egyfelől tekintetbe vehetjük bizonyos jellemzők, vonások meglétét vagy hiányát, másfelől pedig a szakterület befolyását, a kialakuló erőviszonyokat. A jellemzőket a szakterület által ellátott funkciókkal összefüggésben tudjuk meghatározni. Miképpen járul hozzá a terület a jobb társadalmi müködéshez, és mi a tevékenységek jelentősége a társadalom életében? Hogyan alakul a társadalmi ismertség és elismertség? Beszélhetünk-e a feladatok monopóliumáról? Hogyan formálódnak az erőviszonyok a társszakmák képviselőivel? Milyen specifikus szakmai tudásokra építkezik az adott terület, és ezzel összefüggésben léteznek-e önálló kutatási programok, sajátos kutatási módszerek? Hogyan jellemezhető a képzés szerkezete? Vannak-e formális, hatóképes szakmai szervezetek? Van-e a szakterületnek - különösen segítő pályákon - saját etikai kódexe? Miképpen alakul a hivatás presztízse és anyagi megbecsültsége? A Weiss-Gal és Welbourne (2008) által felsorolt listához - további indikátorként - hozzátehetjük még a kutatások terén is alapvető sajátos szakmai nyelv, önálló terminológia kialakulását (Gosztonyi \& Pik, 2011).

Greenwood saját modelljében már 1957-ben meghatározta azokat a kulcsfontosságú jellemzőket, amelyek mentén eldönthető, hogy hivatásról (profession) vagy csak valamiféle szakmai tevékenységről (job) beszélünk. A hivatás ismérvei: a rendszerezett tudásanyag, a szakterülethez kapcsolódó világos jogosultságok, saját etikai kódex, valamint a szakterület önálló kultúrája, és a formális szervezetek létrejötte. Később ezekhez társultak további olyan vonások, mint a speciális szakmai készségek, a huzamos időn át tartó képzés és pályára történő szocializáció - mégpedig a felsőoktatás keretei között -, valamint a kontrollált képzésbe lépés, a szakmai autonómia, az elkötelezettség, a presztízs, a megfelelő javadalmazás, és a jogszabályi keretek között müködtetett kliens-segítő kapcsolat. Mindezek alapján a szakmai autonómiát és más vonásokat is többé-kevésbé még nélkülöző szociális munkát kezdetben félhivatásnak (semi-profession) tekintették. A nyolcvanas években éppen a szakmai tudásbázis gyarapodása - a kutatások eredménye - jelentett előrelépést, és a félhivatalos-félhivatásos státuszt felváltotta a fiatal, fejlődő szakterület meghatározás (Weiss-Gal \& Welbourne, 2008).

A hatalmi, hierarchikus modell szerint azonban az a döntö, hogy az adott szakterület mennyire képes uralma alatt tartani egyes gyakorlati területeket, és hogyan tudja megvédeni saját érdekeit a rivális érdekekkel szemben - jellemzően más hivatásokkal és (gyakran átmeneti, változékony) kormányzati érdekekkel szemben. A koncepció előfeltevése, hogy minden szakterület eleve konfliktusban áll más területekkel, amikor saját határait, erőforrásait, klinseit és jogosultságait védi (Abbott, 1995; Hall, 1994, id. Weiss-Gal \& Welbourne, 2008). Ebben az esetben tehát a gyakorlati területek feletti kontroll mértéke a döntő: mire van monopóliuma a szociális munkának? Ide tartozik a szociális munka eszköztárának körülhatárolása és fejlesztése, a szociális munkások képzése, tevékenységük engedélyhez kötése, a szolgáltatások jellegének, lehetséges klienskörének meghatározása. Láthatóan itt egy vállalati-szolgáltatói modell keretei között gondolkodunk, ami sok szocális munkás számára kissé idegenként hat (Singleton, 2014); és ami ugyanakkor, lássuk be, komoly védelmet biztosít a határterületekről érkező annektálási törekvésekkel, és akár a szakmai színvonal meggyengülésével szemben. Egy fontos hazai példa erre a monopóliumalapításra a mentálhigiénés ellátások területe (Bagdy, 1996), ahol a hazai szociális munka pozíciókat és fontos, a közvetlen klienskapcsolatban nélkülözhetetlen módszereket is vesztett (Szabó, 2017; B. Erdős, 2017). 
A professzionalizáció egy, a nemzetközi színtéren lefolytatott empirikus vizsgálata során Weiss-Gal és Welbourne (2008) a két modell szerint kiválasztott kevert indikátorokat alkalmazták:

- A professzió nyilvános elismerése: a szakma gyakorlásának, a szociális munkás cím viselésének világos kritériumai, jogszabályi háttere, ezzel összefüggésben a szakterület imidzse, társadalmi elfogadottsága.

- Szakmai monopólium a feladatok ellátására: kizárólagos jogosultság egyes szakma feladatok elvégzésére. Egyes területeken erős lehet a versengés a társszakmák között (pl. pszichoszociális tanácsadás, családterápia- és konzultáció, szociálpedagógia, közösségi munka - vagy akár az önkéntes segítők státusza, kompetenciái körüli viták stb.).

- A szakmai munka autonómiája.

- A szakmára specifikus tudásbázis, azaz a szociális probléma, a sérülékeny társadalmi csoportok ismerete, az intervencióra vonatkozó tudások (ideértve ennek értékelését), a beavatkozások szintjeinek és színtereinek, ezek hatótényezőinek ismerete (pl. egyéni/közösségi szint).

- A szakma saját képviselői által szabályozott képzés: milyenek a képzési hagyományok, melyik képzési szint pontosan milyen kimenettel zárul, mire jogosít fel, milyen a képzés minőségbiztosítása, és hogyan alakul a továbbképzések rendszere?

- Hatékony, befolyásos szakmai szervezetek: van-e kötelező, vagy legalább elönyöket jelentő tagsági viszony? Ki és miként látja el a szakszervezeti érdekképviseleti funkciókat? Mennyiben segítik e szervezetek a „társadalmi igazságosság” projektjének érvényre juttatását, azaz az aktivisták társadalmi ügyek mentén történő részvételét, a társadalmi feszültségek, konfliktusok jelzését? Mennyire reprezentatívak, befolyásosak e szervezetek, és milyen módon szabályozzák tagjaikat? Kinek az érdekeit képviselik: a szakmáét, egyes érdekcsoportokét, vagy a kormányzatét?

- Etikai sztenderdek: milyen következményekkel jár az etikai vétség? Mennyire tarthatóak az abban foglaltak az aktuális társadalmi viszonyok közepette? (ld. pl. Németh, 2014).

- A szakma presztízse és a javadalmazás: Miképpen alakul ez a többi segítő-fejlesztő szakterülethez képest? - különösen a klientúra alacsony státuszával összefüggésben.

\section{Problémamegoldó hivatás és kritikai-reflektív hozzáállás}

A szociális munkás azért sajátít el szakmai ismereteket, hogy hatékonyabban segítsen. A kutatásnak nem csupán a tudásbázis építésében, a praxis, a módszerek alakításában lehet kiemelkedő szerepe. A szociális munka problémamegoldó hivatás (Darvas \& Hegyesi, 2003), és mint ilyen, feltételezi az autonómia bizonyos szintjét, hiszen a változó és nagyon komplex problémákra aligha célszerü változatlan megoldásokat felkínálni. A szociális munkás tehát nem lehet a korábbi megoldásokat mechanikusan ismételgető mesterember, de nem bújhat a kliens felett álló, távolságtartó, a megoldásokat a kliens bevonása nélkül felkínáló szakértő vagy menedzser (,,projektmunkás”) szerepébe sem. Olyan reflektív szakemberré kell válnia, aki képes a rendszerszemléletü, holisztikus gondolkodásmódra, felkészültségei egyedi, innovatív és kreatív válaszokat tesznek lehetővé, amelyeket klienseivel közösen alakít ki (Jones \& Joss, 1995; Kozma, 2007; Bányai, 2008; Nagy, 2009; Kelemen \& B. Erdős, 2010). A reflektív 
szakember formális vagy informális módon, élethosszig építi saját tudását, és ennek az építkezésnek a praxis, a kutatás, és az elméleti ismeretek igényes megújítása és integrálása a módja.

A szociálismunka-kutatás és a szociális munka praxis kiindulópontja mindenütt közös: a szociális probléma (Navratil \& Bajer, 2018). A szociális probléma szociális konstrukciója (Szöllösi, 2012) döntő befolyással van arra, hogy egyáltalán mit tekintünk problémának, a problémaként definiált jelenséget megoldandónak, megoldhatónak tartjuk-e, magát a problémakezelést pedig mely szinteken és színtereken tervezzük. A szociális munkások szociális problémákra vonatkozó konstrukciói azonban nem függetlenek a köznapi, ,józan észre" alapozott tudásoktól, sem a média befolyásától. A szakmai ismeretek ezekkel az adott kultúrában elfogadottnak, érvényesnek tekintett tudásokkal kerülnek valamilyen viszonyba: kiegészítik vagy átírják a „mindenki” által ismert és megerősített valóságot (Rubin \& Babbie, 2007). Ma a media mint hatalmi ág elöretörésével és globalizálódásával a hatalmi törekvések egyik legfontosabb eszköze a manipuláció, amelynek felszínén a „csak nektek akarunk jót” hamissága munkál, eredménye pedig a gazdasági kizsákmányolás és a társadalmi kirekesztés súlyosbodása (van Dijk, 2006). Az embernek általában, a segítő szakembernek pedig különösen, azért van szüksége minél pontosabb, árnyaltabb, használhatóbb tudásra, hogy a problémát meg tudja oldani, és saját határai feszegetésével képes legyen a fejlődésre (Horányi, 1999). Ha nem képes a számára szükséges tudások elérésére és alkalmazására, kiszolgáltatottá válik. A manipuláció hatásaitól a szociális munkás sem tudja teljesen függetleníteni magát, hiszen ismereteinek csupán egy része tudományos tudás - és még ez sem mentes elfogultságoktól, torzításoktól (Kincheloe, 2007). Így egyéb, hasznos és haszontalan, reflektált és reflektálatlan tudásaink forrásai, a media, a köznapi és reflektálatlan tapasztalatok, hiedelmek, ideológiák fogják befolyásolni szakmai tevékenységünket (Rubin \& Babbie, 2007).

A kritikai-reflektív gondolkodás segíti a logikai hibák, az elfogultságok, az előítéletesség és a dogmák felszámolását, a gondolkodás nyitottságának, egyszersmind kapcsolatietika-alapú értékorientáltságnak megőrzését, a hatalmi viszonyok befolyásának értékelését, a lehetőségek, az alternatívák explorációját, és a szakmai autonómia kiteljesítését. A kritikai gondolkodás teszi lehetővé a megfigyelések, tapasztalatok, reflexiók, érvelések, viták során keletkező információk rendszerezését, elemzését, szintézisét, értékelését és alkamazását, hogy a szakmai tevékenységeket árnyalt, körültekintő, a releváns nézőpontokat figyelembe vevő és elfogulatlan, kiegyensúlyozott gondolkodás alapozza meg. A kritikai gondolkodás ebből következően társadalmi értelemben méltányos, etikus, és a problémák megoldása terén hatékony is (Paul \& Elder, 2006). Itt nem egy egyszerü készségről van szó: a kritikai gondolkodás a megismerés tartós vonása, a szociális problémák változékonysága folytán nélkülözhetetlen, élethosszig tartó tanulást támogató attitűd. Hazánkban az e téren még hiányos felkészültségek miatt „kritikai” alatt nemegyszer a puszta szembefordulást, a nemet mondást értjük. Ez azonban, ha hiányzik mögüle a megalapozott érvelés, a másik fél szempontjait megismerő és értelmező, az érvelést átláthatóvá, követhetővé tévő kommunikáció, valamint a probléma megoldására tett életképes javaslatok, lehet bátor dolog - de inkább a magánember és nem a szakember viselkedése.

A szakmai autonómia és az érdemi, erőssé-képessé tevő segítő tevékenység megvalósíthatatlan a kritikai-reflektív gondolkodásra való szisztematikus felkészítés és megfelelő nyitottság, érzékenység nélkül - ezek kialakításában a kutatásnak mint szakmai tevékenységnek pedig döntő szerepe van. A képzés során remélhetőleg kialakuló elemzőlogikai készségeket a folyamatos kutatás, a tudás megújításának gyakorlása edzi meg, és tartja 
megfelelő szinten: ez az, ami a kutatást a szakember és az őket képző oktatók nélkülözhetetlen tevékenységévé teszi (Hughes, 2005).

\section{A személy-a-könyezetben fókusz}

A szociális munka, amelynek fókuszában egyszerre áll a személyes-egyéni és a társadalmi, és az interdependenciában mint az emberi viszonylatok valós természetének leképezésében gondolkodik, óhatatlanul támaszkodik a rendszerszemléletủ gondolkodásra (Davies \& Jansen, 1998; International Association of Schools of Social Work [IASSW], 2014; Koestler, 1967; Bateson, 1972), a hálózatok elméletére (Granovetter 1973; Csermely, 2004; Udvari, 2011) és a kapcsolati etikára és felelősségvállalásra (McNamee \& Gergen, 1999).

A szociális munkások többsége közvetlen klienskapcsolatban tevékenykedik, ahol a konzultációs módszerek avatott alkalmazását a szakma hatékony, erössé és képessé tételre irányuló gyakorlata egyértelmüen megköveteli (Lakatos, 2009; B. Erdős, 2017). Ugyanakkor a problémák, amelyekkel szembesül, kétségkívül társadalmi eredetủek is. A gyors perspektívaváltás, a szintek közötti rugalmas közlekedés, az eltérő szinteken és színtereken megszerzett tudás integrálása, a holisztikus látásmód az, ami a kutató számára (is) ennek a transzdiszciplináris területnek az egyik legnagyobb varázsát adja. Ez a készség nem szerezhető meg könnyen. Az amerikai tapasztalatok és dilemmák hazai tükreként Darvas Ágnes és Hegyesi Gábor (2003) egy korábbi vizsgálatuk során felfigyeltek arra, hogy míg a megkérdezett szociális munka szakos hallgatók a társadalmi problémák okait szociológiai, szociálpolitikai eredetűnek vélik, mégis leginkább pszichológiai módszerekkel próbálnak megbirkózni ezekkel. A szociális munkást nyilván nem az elvontan létező társadalmi probléma, hanem a konkrét kliens vagy klienscsoport keresi fel, és neki ott és akkor tennie kell valamit, hogy az adott ügyben pozitív változást érjen el. Ehhez pedig értő-megértő-értelmező kommunikációra van szüksége. Másfelől, maga a kliens is gyakran a személyközi kapcsolatok szintjén definiálja saját problémáját. Lehet, hogy ez a definíció szokatlan formában történik, neheztelés, sírás, kiabálás kíséri - de ez bizony egy olyan problémameghatározás, amelyet, mint a közös munka kiindulópontját, tiszteletben kell tartanunk. A segítőnek felelös döntést kell hoznia arról, hogy - első lépésben - tanácsadóként a kliens személyes életének vezetését segítse, vagy érdekképviselöként az ártalmas környezeti hatásokat próbálja meg mérsékelni (Rubin \& Babbie, 2007).

A baj akkor van - a praxist, a kutatást, és az oktatást tekintve egyaránt - ha a személya-környezetben fókusz tartósan sérül, azaz a hangsúly túlságosan egyoldalúan kerül az egyik, a személyes, vagy a másik, a társadalmi szintre. A szakma többoldalú, többszintü meghatározottsága a hazai képzésekben a már említett, szakmai monopóliumokat meghatározó vita következtében Magyarországon ma kevésbé juthat érvényre. A társadalmi dimenzió mellett a társas háttérbe szorulása azért is problémás, mert így megfelelő eszközök híján a válságos élethelyzetbe került személyeket nem tudjuk elég hatékonyan segíteni abban, hogy saját helyzetükön képesek legyenek változtatni. A pszichoszociális tényezők, az interszubjektív tartomány figyelmen kívül hagyásával ugyanakkor megnő a veszélye annak is, hogy kliensünk a közös munka alanya helyett a beavatkozás tárgyává válik, a szemünkben éppolyanná, ahogyan a médiában mutatják a szegényeket: élettörténet nélküli, identitás nélküli nem-személyekként (Hammer, 2004). A társadalmi szint negligálásának pedig többek között az a veszélye, hogy az egyedi beavatkozások, esetkezelések egy befogadó, a reintegrációt segítő környezet nélkül sokkal kevésbé lesznek hatásosak. 


\section{Kvantitatív vagy kvalitatív? Kvalitatív és kvantatív!}

Milyen kutatási stratégiák, megközelítések illeszthetőek a szociális munka személy-akörnyezetben fókuszához? A komplex, önszerveződésre, önmaguk megújítására, változtatására képes rendszerek kutatásával eleve együtt jár a sokszempontúság, az emberi kultúra és nyelv természetének a megismerésben, különösen pedig a társadalmi jelenségek megismerésében játszott megkerülhetetlen szerepe (Mingers, 1991). Az ezekhez kapcsolódó új típusú filozófiailogikai megközelítések (pl. abduktív logika, fuzzy logika) azonban szokatlanul hatnak egy pozitivista hagyományokkal túlterhelt környezetben. A szociális munka kritikai-reflektív gondolkodást megkövetelő területének megkerülhetetlen elméleti alapja a szociális konstrukcionizmus (Szöllősi, 2012; Kelemen, 2011; Kincheloe, 2007; Mejía \& Molina, 2007; Paul \& Elder 2006).

A hazai társadalomtudományi kutatások többnyire még mindig a nagy minták és a statisztikai elemzések büvöletében zajlanak. A szociális munkás célcsoportja azonban nemegyszer éppen az a csoport (pl. egy addiktológiai helyzetkép, felmérés esetén), amelyik a kutatás színterén nincs is jelen - például azért, mert éppen a vizsgált problémával összefüggésben már lemorzsolódott a közoktatásból, ami a kutatás aktuális színtere. A nagy adatbázisokból nyert eredményekre - legyen szó foglalkoztatásról, szegénységről, addiktológiáról, vagy éppen „csak” az életmódról - a szociális munkások nemegyszer rácsodálkoznak, mert ezek ellentétesek napi tapasztalatukkal (Bányai, 2018). Az is igaz ugyanakkor, hogy tapasztalataikat éppen a legnehezebb élethelyzetben lévők körében szerzik ettől pedig úgy tünhet, hogy e problémák a valóságosnál kiterjedtebbek. Ám az ellentmondás a szakirodalmi adatok és a szakmai tapasztalatok között gyakran előfordul, és ez a helyzet további, célzott vizsgálatokat igényelne, mégpedig kevert (integrált) módszertan szerinti elrendezésben (ld. pl. Palinkas és mtsai., 2015). Az ilyen vizsgálatokat azonban területünkön megnehezíti, hogy a társadalomtudományi és a szociálismunka-kutatás különbségét - amely a kutatás céljában, az alkalmazott módszerekben egyaránt megfogható - hazánkban korábban nem definiálták.

Mit akar a szociális munkás szakemberként? Milyen kérdései vannak? Ezek a kérdések gyakran a tanácsadó és kvalitatív kutató azonos kérdései: Milyen ez a személy/család/csoport stb? Tudnak-e bízni bennem? Mit fognak tenni? Mi segíti, és mi gátolja azt, hogy egymással jó, konstruktív kapcsolatba kerüljünk? Mi és ki a fontos az életükben? Mi minden motiválja őket? Miben gondolkodnak másként az adott problémáról, mi ennek a gondolkodásmódnak az eredete, és melyek a lehetséges következményei? Milyen problémát oldanak meg valójában a jelenleg felkínált megoldások, mi az a probléma, amire ez a megoldás? (Reynolds, 2014)

A praxis sajátosságaiból és fejlesztési igényeiből fakadó különbségek Magyarországon is létrehozták a kiindulópontokat az áttervezéshez. A szociális munkásnak kétségkívül képessé kell válnia a statisztikai adatok értelemzése, egyúttal ezek korlátainak kritikai értelmezésére, de emellett gyakorolnia kell mindazokat a kutatási módszereket, amelyek a praxisból érkező tudások közvetítésére a legalkalmasabbak.

„a szociális munkások azonban sokszor nincsenek birtokában annak a szociológiai tudásnak, mely a kérdőívek helyes összeállításánál, a megfelelő mintavételi eljárásnál (kis elemszám) és a kérdőívek elemzésénél (spss-tudás) szükséges lenne. Ez gyakran vezethet rossz következtetések levonásához, hibás végeredményekhez. A kvalitatív kutatási módszerek alkalmazásához, mint például az interjúzáshoz szükséges szaktudással viszont rendelkeznek a szociális területen dolgozók." (Sik \& Szécsi, 2015: 88-89) 
Az idézett szerzők optimistán állnak a kvalitatív kutatásmódszertani ismeretek elsajátításának kérdéséhez: nem biztos, hogy ez az optimizmus ma indokolt. Egy jó kvalitatív kutatás megtervezése és kivitelezése semmivel sem igényel kevesebb felkészültséget, mind a kvantitatív módszerek alkalmazása, ugyanakkor kevés a kvalitatív módszertanban járatos oktató és kutató. Ráadásul a gyakorlati munkában az utóbbi években visszaszorulóban van az érdemi, kellő mélységeket elérő segítő beszélgetés, vele együtt az interjúzás. Ám az biztos, hogy a valós szükségletek a szociálismunka-kutatásra vonatkozóan egy teljesen más kutatásmódszertan-oktatás alapjait rajzolják fel.

A kvalitatív kutatás gyakorlásának egy további előnye, hogy önmagában is segít kialakítani a helyes viszonyt segítő és kliense között (például ilyenkor eleve elkezdünk gondolkodni azon, hogy mit is jelent a „kliens” kifejezés). Jó szociálismunka-kutatást nem lehet paternalista stílusban, távolságtartóan vagy elfogultan végezni (B. Erdős, 2017). A szociális munka területén, mind a praxisban, mind a kutatásokban, gyakori az élményszerü tudásokkal, sajátos ismeretekkel és felkészültségekkel rendelkező szakember, a tapasztalati szakértő bevonása (Bajzáth, Tóth \& Rácz, 2014; Bányai, 2018), a fejlesztő szempontú (akciókutatás jellegü), közösségi alapú részvételi kutatás. A kvalitatív kutatás gyakori, deklarált célja az elnyomott csoportok jobb társadalmi részvételének biztosítása, hangjuk (voice) felerősítése, a kultúrájukra, közösségi kapcsolataikra érzékeny leírások, értelmezések létrehozása (Rubin \& Babbie, 2007).

Humberto Maturana, akit a kogníció biológiája, az önszerveződő, autopoetikus rendszerek leírása tett világhírűvé, 1996-ban egy nemzetközi családterápiás konferencia (IFTA) plenáris előadásában kiemelte, hogy a megismerés feltétele a szeretet. Bármit is szeretnék megismerni, el kell fogadnom aktuális adottságait, megnyilvánulásait, azaz „természetét”, és kellö közelségbe kell kerülnöm hozzá ahhoz, hogy megismerhessem. Természetesen fordítva is igaz: a szeretet feltétele a megismerés. Kliensünk nemritkán nehezen szerethető emberként mutatkozik be: dühös, neheztelö, kétségbeesett, ambivalens, tehetetlen. A kellően árnyalt elemzések azonban segítenek abban, hogy elkerüljük az áldozat hibáztatásának csapdáját.

„A domináns diskurzusban (és a jogban) a szenvedélybeteg, különösen az illegális szereket használó személyre bünösként tekintünk (lineáris okság). Azt ritkán vesszük észre, hogy egyben persze áldozat is: mert maga is gyakran bántalmazó, szerhasználati problémákkal terhelt családban nőtt fel (cirkuláris okság, rendszerszemlélet). A társadalmi megítélés nem méltányos; de nem is hasznos, mert nem segít a megoldáshoz közelebb jutni." (B. Erdős, Vojtek \& Borda, 2019)

\section{A szociálismunka-kutatások szerepe a szakma gyakorlásához és fejlesztéséhez szükséges tudás felépítésében}

Megfelelö, a fejlődési célok kijelöléséhez szükséges tudásbázis kialakítása nem lehetséges emprikus vizsgálatok elvégézése nélkül. A tudásbázis alakulásának mutatói a kutatómunka, az elméleti fejlesztések mennyisége és minősége, a gyakorlati szakemberek bekapcsolódásának mértéke a kutatásba, a minőségi szakmai lapok, mérvadó fórumok, konferenciák széles körü elérhetősége és a szakmai szervezetek ereje. A Council of Social Work Education (2008) a szociális munkások tevékenységeinek felsorolásakor kiemeli a kutatás szerepét a szakmaiságban: a szociális munkás „tudományos kutatásra alapozott ismeretek által vezetve” végzi tevékenységét. 
Ehhez kapcsolódó éles kérdésként vetődik fel szakmai praxisból érkező, vagy még inkább nem érkező tudások ügye. A praxis változékony, az innen kapott visszacsatolások mindig komplexek, sokoldalúak. Wenger (2004) szerint azok a tudások, amelyekre az adott terület döntéseit alapozzák, általában a széleken, a margón keletkeznek, és a döntéshozókhoz el sem jutnak, így ök egy információs vákuumból próbálják irányítani a szükséges fejlesztéseket. Wenger eme lyukasfánkmodellje (a lényeg ugyanis a széleken van, a centrum pedig üres) nagy vihart kavart a tudásmenedzsmenttel foglalkozó szakemberek körében; annyi bizonyos, hogy a hiányzó kommunikációs hálózatok és visszacsatolások bármely rendszer müködését ellehetlenítik, megbénítják, értelmetlenné teszik.

A szociálismunka-kutatások nagyon nagy erőssége az alkalmazott jelleg, a gyakorlattal való közvetlen kapcsolat. A szociális munkás a kutatómunka során éppúgy az emberi szenvedés enyhítését tüzi ki céljául, mint bármely más szakmai tevékenysége során: kérdésfeltevése a praxisban gyökerezik, ebben az értelemben releváns (Rubin \& Babbie, 2007). Mint reflektív szakember (Kelemen, 2011), tudatában van annak, hogy a változó környezetben a változó kérdések folytonos vizsgálatára lesz szükség, hiszen a tudás soha nem végleges. Tekintettel arra, hogy sérülékeny csoportokat, kockázati helyzeteket vizsgál, fokozott figyelmet kell fordítania kutatómunkája etikai vonatkozásaira (Madácsy, 2020), ügyelve a legfontosabb kérdésekre: melyek a kutatás lehetséges veszélyei, mi a várható haszna? Hogyan biztosítható a kutatás során e csoportok megfelelő képviselete?

A szociális munka gyakorlatorientáltsága, sajátos kontextuális, személy-a-környezetben fókusza ebben a hazai közegben kutatói, kutatásszervezési és képzési dilemmákat vet fel. A szociálismunka-kutatás óriási kihívás a képzőintézményeknek, mert azt jelenti, hogy kutatásmódszertani kurzusaikat teljesen meg kell újítaniuk, és a saját irányításuk alá kell vonniuk. Maguknak az oktatóknak is fejlődniük kell a kvalitatív kutatások, az alkalmazott kutatások terén, a szükségletfelmérésben és a programértékelésben. A megújulás erőfeszítéseket jelent, egyszersmind azonban energiákat szabadít fel.

Ma még „természetes”, hogy hazánkban a szociális munkásoknak nincs saját doktori iskolája, de még önálló doktori programja sem. A más programokba kerülö hallgatóknak alkalmazkodniuk kell:

„,nekem az nem tetszett, hogy azt láttam az ilyen párbeszédeknél, hogy teljesen különvált a kutatás, meg annak a gyakorlati hasznosíthatósága. Tehát a kutatás a lényeg: hogy legyen meg a kutatás. Az, hogy a kutatás nem járul hozzá gyakorlatilag semmihez... a szociálismunkás-képzés ugye nagyon gyakorlatorientált, és én folyamatosan azokat a kérdéseket tettem föl... én értem, hogy van itt egy kérdés, és kutassuk, de miért? És egyébként ennek mi a haszna a gyakorlatban dolgozó szakemberek számára, és ők hogyan tudják ezt felhasználni, ennek az eredményét? (...) Nem is tudom, hányan voltunk egy évfolyamban, és körülbelül kettő kutatásra tudtam volna azt mondani, hogy tényleg, ha ez így jól meg van csinálva, és valaki jól megírja, és kezébe veszi mondjuk ezt a munkát egy gyakorlatban dolgozó szakember: »hú, ez igen, ez tudja az én munkámat segíteni«. Tehát engem egy kicsit ez zavart, hogy kutassunk, kutassunk, nem biztos, hogy ez, lesz valami gyakorlati hatása, de azért csináljuk (...) Az oktatók mindig afelé tolták a hallgatókat, hogy módszertanilag kutatható legyen."1

Az MTA szakterületi bizottságai (különösen a szociológiai és a pszichológiai) által támogatott folyóiratok: Szociális Munka (szünetel), Addiktológia (esetlegesen tud megjelenni);

\footnotetext{
${ }^{1}$ Az EFOP 3.4.3.-16-2016-00005, „Korszerủ egyetem a modern városban: Értékközpontúság, nyitottság és befogadó szemlélet egy 21. századi felsőoktatási modellben” c. projekt kereti között készült interjú szövegéből.
}

Szociális Szemle, 12. évfolyam, 1-2. szám (2019) 
az Esély a szociológia területén támogatott; az angol nyelvű irodalmak esetében szintén a szociológia területén jobbak a kilátások.

A gyakorló szociális munkások a számos, e területen szerzett frusztráló tapasztalatuk miatt ritkán érzik feladatuknak a kutatást. Lemaradásunk e területen nem is sokkal kevesebb, mint az a nevezetes, kemény és puha diktatúrákban eltöltött fél évszázad.

\section{A diagnózisok társadalmi csapdái}

A hazai szociális munkások számos elméletet, gyakorlati módszert próbáltak importálni az angolszász országokból. A magyar kontextusban ezek adaptálása nem mindig volt - és nem is lehetett - sikeres. Rendre elmaradtak például a szisztematikusan alkalmazott, megfelelő kutatói logika, gazdag módszertani felkészültség és elegendő forrás birtokában végzett értékelő kutatások, amelyek megmutatták volna, mi az, ami müködik, mi az, ami nem, hol vannak a kulcsfontosságú eltérések a kívánt, várt állapot és a valóság között, és mitől várható a helyzet javulása, azaz melyek a szakma igazi jó gyakorlatai és módszerei (Ellis \& Hogard, 2006; B. Erdős, 2010; B. Erdős \& Vojtek, 2018).

A szociális munkához hasonló inter- és transzdiszciplináris területeket övező flexneri gyanakvás hazánkban ma még különösen erős és eleven. Talán a korábbi szovjet, az egyes tudományterületeket mesterségesen elválasztó akadémiai hagyományok is közrejátszottak ebben. Az emberi élet viszont a maga komplexitása folytán aligha rendezhető el szük diszciplináris keretek mentén. A szociálismunka-kutatásokat ma - ha ezek egyáltalán megjelennek - a társszakmák uralják, az alkalmazott társadalomtudományi kutatások presztízse általában csekély. A neopozitivista fóáramban nehéz szociális konstrukcionista nézőpontokat megjeleníteni, pedig ezeknek nagyon is ott a helye azokon a pontokon, ahol nem természettudományos, hanem társadalomtudományi kutatások folynak, azaz a kutatás tárgya nem a dolog maga, hanem sokkal inkább az arról alkotott képünk (Harré, 2004). Jól látható ugyanakkor, hogy a szociálismunka-kutatás, éppen a szakma komplexitása folytán, meglehetősen nehéz müfaj. Számunkra éppen a komplexitás és a gyakorlatorientált jelleg miatt evidencia, hogy a statisztikák mögé kell néznünk, mielött bármilyen következtetést levonnánk ezek alapján. Mitől szenvedélybeteg? Mitől munkanélküli? Mitől hátrányos helyzetü? Hasznos leírásokat eredményez-e ez a deficitnyelv? (Cooperrider \& Whitney, 1999)

Amikor szakmai gyakorlatokat, módszereket feltárva lépéseket teszünk a professzionalizáció felé, az egyik legnagyobb veszély éppen a merev, dogmatikus megközelítés, amiből a sztenderdizáció árnyoldala (Bányai, 2008), a szakmai autonómiát és kreativitást, sőt a kliens fejlődését gátló, az áldatlan társadalmi viszonyokat konzerváló puszta „kontrollmunka” lehet. „Manapság sajnos gyakori, hogy a szociális munkások tevékenysége abban merül ki, hogy felügyelik, amint az emberek élete tönkremegy." (Jones és mtsai., 2004) A diagnózis segítheti a problémák megoldódását, de megadhatja a lehetőséget arra is, hogy komplex magyarázatok helyett beérjük egyszerü tautológiákkal - és az egyre romló, de tudományosan „megmagyarázott”, rögzített értelmezési keretben megmutatott emberi sorsok szemlélésével. A diagnózis, mint minden definíció, lezár és határokat szab, egyes esetekben pedig önmagát beteljesítő jóslat módjára működik. A probléma leírása, akár akarjuk, akár nem, bizonyos értelemben mindig elöírásként is müködik (Sacks, 1993; Rácz, 2001), s megvan a veszélye annak is, hogy a személyeket összekeverjük diagnózisaikkal (Singleton, 2014).

Amerikában a pszichodinamikus irány, egyáltalán, a pszichológiai módszerek tartós népszerüsége mögött egy politikai ok állt: a szocializmustól, később a kommunizmustól való 
intenzív félelem (Blundo, 2006). Jobbnak tünt a szociális munkásokat távol tartani azoktól az irányoktól, amelyek az akkori kapitalista társadalmi müködés visszásságait feszegették. A szakma hazai fejlődéstörténetében is a pszichodinamikus iskolák játszották a meghatározó szerepet - érthetö, hiszen a pszichológiában is ez jelentette a várva várt és méltó visszatérést a budapesti iskola megszakított hagyományaihoz. Így azonban nagyrészt kimaradt az életünkből a posztmodern fordulat, a narratív vonal, a megoldásközpontú, erősségekre építő, a szociális munkás természetes munkamódszerét jelentő tanácsadói, egyben a kvalitatív kutatói készségeket is fejlesztő megközelítés (Cooper \& Lesser, 2002; Rubin \& Babbie, 2007; Hogard, 2007; B. Erdős, 2017). A pusztán okokra és problémákra összpontosító gondolkodás nem mindig segít az egyes esetek megoldásában. Nagyobb erő lehet a megoldásközpontú gondolkodásban, amelynek legfontosabb üzenete, hogy a kliensre nem patronálásra szoruló gyámoltalan lényként, hanem autonóm cselekvőként, személyként tekintünk (Saleebey, 2006). A hazai írásokban ritkán említik meg ezeket az irányokat (ld. pl. Budai \& Puli, 2015; B. Erdős, 2017), és a szükre szabott expozíciót elbátortalanító kritika követheti (Temesváry, 2018). Így azonban háttérbe szorulhat a kliens önkéntes részvételének, elköteleződésének, aktivitásának hangsúlyozása. A változásra, fejlődésre való motiváció még gyakran előhozható volna, bár elfedik a torzult értelmezési keretek, a jelentéstulajdonítások, vagy akár a hivatalos viszonyok (Evan, Iveson \& Ratner, 1990). Miképpen ismerhetjük meg ezeket korszerü, a klienseket is bevonó szociálismunka-kutatási módszerek nélkül?

A diagnosztikus gondolkodásmódra való áttérés, bár elősegítheti a professzionalizációt, máig tartó vitákat generál. Fontos lenne, hogy a diagnózis a legkorszerübb tudományos ismeretekre épüljön:

A szociális diagnózisnak hazánkban nem a problémacentrikusság, a disempowerment az egyetlen
negatív vonása, hanem a diagnosztikai kategóriák keveredése, elmosódása, a transzdiszciplináris
megközelítés hiányossága is. A szerhasználó kontrollvesztését, a pszichiátriai beteg
impulzuskontroll-zavarát, és az egyes betegségeknél fellépő inkontienciát egy kalap alá venni
éppen olyan, mintha valaki villanykörtét uzsonnázna körte helyett: „,(6.2) Vannak-e problémái a
kontroll tartásával? Akkor kell feltenni ezt a kérdést, ha az előző kérdésekböl, vagy a
problémafelvetésböl kiderül, hogy az igénylö szerhasználata vagy mentális problémák miatt
nehéz számára a kontrollt tartani, vagy a diagnózis felvétele során kontrollvesztésre utaló
magatartást tanúsít, illetve erre utaló információ hangzik el. Egyes belgyógyászati betegségek
ugyancsak kontrolltartási (pl. ürítési) nehézséget okozhatnak, ami az érintett mindennapi
életvitelét, társas kapcsolatait, munkavállalását korlátozhatja. A kérdés tisztázásánál figyelembe
kell venni ennek kényes, intim tartalmát!” (Útmutató a szociális diagnózis elkészítéséhez, 2019:
5) 5)

A mégoly pontos és árnyalt diagnózis is csak akkor jelent segítséget a szakember számára, ha tisztában van vele, hogy saját szerepe mindenkor a konstruktív változások lehetséges maximumának előmozdítása, a felelősségvállalás, az autonómia elősegítése. Az utóbbi időben már sokféle „diagnózist” használunk (és most itt nem pusztán a szociális diagnózisra utalok): olyasmiket, mint a hátrányos helyzetü, szegregált, kirekesztett, sajátos nevelési igényü, fogyatékkal élő stb. Ezeket a címkéket ugyanolyan céllal használjuk, mint az orvos a betegségek megnevezését. Lehatároljuk a problémát, jelezzük a teendőket, kommunikáljuk saját monopóliumunkat. Ezzel a beszédmóddal azonban nem csupán saját pozícióinkat, de a kliensekét is meghatározzuk. Milyen érzés lehet ilyen identitáselemek akaratlan birtokosává válni? Milyen jövőkép, milyen lehetőségek, milyen cselekvések következnek ezekből az identitáselemekből? Kinek az érdeke ez? (Ezzel összefüggésben ld. pl. Gans, 1992.) 
„a szociális munkások úgy tesznek, mintha nem látnák, hogy maga a szakma gyakorlata miképpen járul hozzá a problémák konzerválásához és a társadalmi igazságtalanság kiterjesztéséhez csupáncsak azért, hogy tehessük, amit általában teszünk. A szakma gyakorlata segíti elő, hogy a domináns, privilegizált csoportok egyre mélyebben avatkozzanak be a szociális munka célcsoportjainak életébe. A társadalmi igazságosság lesz az a diszkurzív jelzőfény, aminek jegyében szabadon tehetünk fel kérdéseket vizsgálódhatunk, sőt felügyelet alá vonhatjuk a szegényeket, a színeseket és a többi alárendelt csoportot." (Margolin, 1997, id. Olson, 2007: 60)

\section{Összegzés}

Miképpen mozdulhatunk a professzionalizáció kockázatait és problémáit megtestesítő jelenségektől a megoldások felé? Egy ilyen lépés erősebb nemzetközi beágyazódáshoz, színvonalasabb szolgáltatásokhoz, a kontrollmunka fenyegetö árnya helyett a fejlesztési fókusz érvényre juttatásához, és (talán) a kölcsönös támadások helyett a kockázatviselök érdemibb, értőbb párbeszédéhez vezethetne. A professzionalizáció projektje és a társadalmi igazságosság projektje között feszülő látszólagos ellentmondás a professzinalizáció egyes dimenzióira vonatkozik csupán. Biztosan nem érinti az etikai és a tudásbázis szociálismunka-kutatások révén történő építésére vonatkozó kritériumokat. Ráadásul a professzionalizáció körül kialakult szakmai vita kérdései (Olson, 2007; Bányai, 2008; Singleton 2014) valószínüleg más válaszokat követelnek azokban a társadalmakban, ahol a szakterület több mint száz évre visszamenő erős hagyományokra építhet, és másokat ott, ahol a stabilitás hiánya, a gyorsan változó társadalmi, ideológiai-politikai környezet szabja meg a teendőket. A szociális munka a 21. század elejére már 144 országban honosodott meg, olyan területeken is, ahol a modernizáció felgyorsulásával jelent meg az igény - így pl. számos afrikai ország mellett a Közel-Keleten és két évtizede Kínában is (ld. pl. Yan \& Tsang, 2007). Bár a szociális munka, a payne-i szociális munkák szükségszerüen építenek lokális ismeretekre, és a szakterület művelését nagymértékben meghatározza az adott társadalmi kontextus (IASSW, 2014; Payne, 2014; Szöllősi, 2015), jól látható, hogy az egyik legfontosabb közös nevező a praxis szolgálatában álló, abból építkező kutatómunka, a kutatási eredmények nemzetközi térben való megjelenítése és az összehasonlításokból épülő új tudások.

\section{Irodalom}

B. Erdős M. \& Kelemen G. (2011). The finite universe: Discursive double bind and parrhesia in state socialism. History of Communism in Euope, 2, 281-309.

B. Erdős M. (2010). Értékelő kutatások a szociális szférában: A Trident-módszer. Szociális Szemle, 3(1), $30-40$.

B. Erdős, M. (2017). Az erősségekre építő megközelítésben rejlő lehetőségek a klinikai szociális munka területén. In (s.n.) (szerk.), Človek s duševnou poruchou ako klient sociálnej práce: Zborníkz medzinárodnej vedeckej konferencie (pp. 275-294). Ruzomberok: Katolicka Univerzita v Ruzomberku, Teologicka Fakulta Kosice.

B. Erdős M. \& Vojtek É. (2018). Értékelő kutatásról, programértékelésről szociális szakemberek számára. Pécs: PTE BTK TKI Közösségi és Szociális Tanulmányok Tanszék. http://szockepzes.hu/wp-content/uploads/2019/02/\%C3\%89rt\%C3\%A9kel\%C5\%91kutat\%C3\%A1s_BEM-V\%C3\%89.pdf (Letöltés: 2019. 01. 02.)

B. Erdős M., Vojtek É. \& Borda V. (2019). Valami új, valami régi: Az új pszichoaktív szerhasználat problémája kapcsolathálózati megközelítésben. In Fábián G. \& Hegyesi G. (szerk.), A 
tudományos gondolkodás és kutatás szerepe a szociális munkában. Debrecen: Debreceni Tudományegyetem. (Közlésre elfogadva, megjelenés alatt.)

Bagdy E. (1996). A Klinikai Pszichológiai Szakkollégium állásfoglalása a mentálhigiéné, a segítő szakmák és a klinikai pszichológiai és viszonyának kérdésében. Család, Gyermek, Ifjúság, 4(37), 3-5.

Bajzáth S., Tóth E. Zs, \& Rácz J. (2014). Repülök a gyógyszerrel: A kábitószerezés története a szocialista Magyarországon. Budapest: L'Harmattan Kiadó.

Bányai E. (2008). A sztenderdizáció árnyoldalai. Kapocs, 7(2), 1-18.

http://www.ncsszi.hu/kiadvanyok/kapocs-letoltheto--lapszamai/kapocs-2008/85/news.

(Letöltés: 2020. 05. 16.)

Bányai E. (2018). Szociális munka élettörténeti interjú Gosztonyi Gézával. Párbeszéd, 5(2). http://parbeszed.lib.unideb.hu/megjelent/html/5b6019c8d96c1 (Letöltés: 2019. 01. 20.)

Bateson, G. (1972). Steps to an Ecology of Mind. Chicago: University of Chicago.

Beckerman, A. H. (1978). Differentiating between social research and social work research. Journal of Education for Social Work, 14(2), 9-15.

Blundo, R. (2006). Shifting our habits of mind: Learning to practice from a strength perspective. In D. Saleebey (Ed.), The strength perspective in social work practice (pp. 25-60). Boston: Pearson.

B. Talyigás K. \& Hegyesi G. (2014). Honnan indult a szociális munka oktatása és gyakorlata idehaza, és hol tart most? Szubjektív áttekintő és köszöntő. Párbeszéd, 1(1-2). http://parbeszed.lib.unideb.hu/megjelent/html/551a4bcae814d (Letöltés: 2018. 12. 10.)

Buda B., Andorka R., György I. \& Donga, K. (1986). Társadalmi beilleszkedési zavarok Magyarországon. Budapest: Kossuth Könyvkiadó.

Budai I. \& Puli E. (2015). Együttmüködés a szociális szolgáltatásokban. Esély, 27(1), 32-64. http://www.esely.org/kiadvanyok/2015_1/2015-1_1

2_budaipuli_egyuttmukodes_szocszolgban.pdf (Letöltés: 2018. 06. 25.)

Cooper, M. G. \& Lesser, J. G. (2002). Clinical social work practice: An integrated approach. Boston: Allyn \& Bacon.

Cooperrider, D. L. \& Whitney, D. (1999). Appreciative inquiry. San Francisco: Berrett-Kochler Communications Inc.

Council on Social Work Education (2008). Educational Policy and Accreditation Standards. https://www.cswe.org/Accreditation/Standards-and-Policies/2008-EPAS (Letöltés: 2018. 10. 12.)

Csapláros N. (2017). Kábitószerprobléma kezelése Baranya megyében a rendszerváltozás idején és napjainkban. A Magyar Addiktológiai Társaság XI. Országos Kongresszusa. Siófok, Magyarország, 2017. 11. 30.-2017. 12. 02.

Csermely P. (2005). A rejtett hálózatok ereje: Hogyan stabilizálják a gyenge kapcsolatok a világot? Természet Világa, 136(4), 146-150.

Darvas A. \& Hegyesi G. (2003). Hungary. In I. Weiss, J. Gal, \& J. Dixon (Eds.), Professional ideologies and preferences in social work: A global study (pp. 125-141). Westport: Praeger Publishers.

Davis, D. R. \& Jansen, G. G. (1998). Making meaning of Alcoholics Anonymous for social workers: Myths, metaphors, and realities. Social Work, 43(2), 169-182.

Ellis, R. \& Hogard, E. (2006). The Trident: A three-pronged method for evaluating clinical, social and educational innovations. Evaluation, 12(3), 372-383.

Evan, G., Iveson, C. \& Ratner, H. (1990). Megoldásközpontú terápia: A de Shazer-modell. Budapest: Animula.

Gans, H. J. (1992). Mire szolgálnak az érdemtelen szegények? Esély, 4(3), 3-17. http://www.esely.org/kiadvanyok/1992_3/mireszolgalna.pdf (Letöltés: 2019. 07.1 2.)

Giczey P. (2015). A settlementek esélyei Magyarországon. Parola, 26(4). http://www.kka.hu/_Kozossegi_Adattar/parolaar.nsf/nyomtat/20323E5ED16D8656C1257F13 005AC5DB?OpenDocument. (Letöltés: 2018. 10. 11.) 
Goffman, E. (2009). Stigma: Notes on the management of spoiled identity. New York: Simon and Schuster.

Gosztonyi G. \& Pik K. (2011). A Szociális Munka Szótára. http://www.macsgyoe.hu/letoltesek/fogalomtarak/2011-10-18/gosztonyi pik_a_szocialis_munka_szotara.html. (Letöltés: 2019.07. 16.)

Granovetter, M. (1973). The strength of weak ties. American Journal od Sociology, 78(6), 1360-1380.

Greif, G. L., Chaiklin, H. \& Timlin, S. (2010). Influential social workers: A preliminary exploration of social work faculty. Social Work and Society, 8(1) 136-147.

Hammer F. (2004). Közbeszéd és társadalmi igazságosság. Médiakutató, 5(1), 7-24. https://mediakutato.hu/cikk/2004_01_tavasz/01_kozbeszed. (Letöltés: 2020. 03. 20.)

Harré, R. (2004). Discursive psychology and the boundaries of sense. Organization Studies, 25(8), $1435-1453$.

Hobbs, E. \& Evans, N. (2017). Social work perceptions and identity: How social workers perceive public and professional attitudes towards their vocation and discipline? Aotearoa New Zealand Social Work, 29(4), 19-31.

Hogard, E. (2007). Using consultative methods to investigate professional-client interaction as an aspect of process evaluation. American Journal of Evaluation, 28(3), 304-317.

Horányi Ö. (1999). A kommunikációról. In Béres I. \& Horányi Ö. (szerk.), Társadalmi kommunikáció (pp. 22-34). Budapest: Osiris Kiadó.

Hughes, M. (2005). The mythology of research and teaching relationships in universities. In R. Barnett (Ed.), Reshaping the university: New relationships between research, scholarship and teaching. Buckingham: Open University Press.

International Association of Schools of Social Work (IASSW) (2014). Global Definiton of Social Work. https://www.iassw-aiets.org/global-definition-of-social-work-review-of-the-global-definition/ (Letöltés: 2019. 01. 20.)

Jones, C., Ferguson, I., Lavalette, M. \& Penketh, L. (2004). Social work and social justice: A manifesto for a new engaged practice. http://www.socialworkfuture.org/articles-resources/ukarticles/103-social-work-and-social-justice-a-manifesto-for-a-new-engaged-practice (Letöltés: 2017. 10. 28.)

Jones, S. \& Joss, R. (1995). Models of professionalism. In M. Yelloly \& M. Henkel, M. (Eds.), Learning and teaching in social work: Towards reflective practice (pp. 15-33). London and Bristol, Pennsylvania: Jessica Kingsley Publishers.

Kelemen G. \& B. Erdős M. (2010). Health learning as identity learning in the therapeutic community. Addiktológia: Addictologia Hungarica, 9(3), 216-225.

Kelemen G. (2011). Átlendülés: Vázlatok a reflektív klinikai szociális munkához. Budapest: Animula.

Kincheloe, J. L. (2007). The power of difference in knowledge production: Multilogicality in the bricolage and postformalism. http://freireproject.org/content/critical-pedagogy-and-research (Letöltés: 2010. 10. 21.)

Koestler, A. (2000). Szellem a gépben. Budapest: Európa.

Kozma J. (2007). A szociális munka professzionalizációja a jóléti államokban. http://www.ncsszi.hu/files/1147.file (Letöltés: 2019. 06. 30.)

Lakatos, K. (2006). A képessé tétel folyamata. Budapest: Közösségfejlesztők Egyesülete.

Madácsy, J. (2019). Kutatásetikai irányelvek a szociális munkában. In Fábián G. \& Hegyesi G. (szerk.), A tudományos gondolkodás és kutatás szerepe a szociális munkában. Debrecen: Debreceni Tudományegyetem. (Közlésre elfogadva, megjelenés alatt.)

Maschi, T., Youdin, R., Sutfin, S. \& Simpson, C. (2012). Social work research and evaluation: Foundations in human rights and social justice. Boston: Pearson.

McNamee, S. \& Gergen, K. (Eds.) (1999). Relational responsibility: Resources for sustainable dialogue. Thousand Oaks: Sage.

Meija, A. \& Molina, A. (n.d.). Are we promoting critical autonomous thinking? Observation of conversational genres can help us answer that question - but it is not enough. 
http://www.prof.uniandes.edu.co/ jmejia/PDF/are_we_promoting_critical_autonomous_thinki ng.pdf (Letöltés: 2019. 09. 01.)

Miller, R. B. (2002). Crisis and responses: The politics of the social sciences in the united states (19801982). http://histoire-cnrs.revues.org/548 (Letöltés: 2016. 03. 26.)

Mingers, J. (1991). The cognitive theories of Maturana and Varela. Systems Practice, 4(4), 319-338.

Nagy K. (2009). Professzionalizáció- és professzióelméletek a segítő hivatások tükrében. Esély, 14(2), 85-105. http://www.esely.org/kiadvanyok/2009_2/005NAGY.pdf (Letöltés: 2018. 10. 30.)

Navrátil, P. \& Bajer, P. (2018). Social construction of social work identity in the processes of its institutionalisation. Annals of Social Sciences \& Management Studies, 1(3). doi:10.19080/ASM.2018.01.555563. (Letöltés: 2019. 12. 01.)

Neményi M. \& Csepeli Gy. (2002). Önsegítés és szociálpolitika. In Lengyel Zs. (szerk.), Szociálpszichológia: Szöveggyüjtemény (pp. 446-453). Budapest: Osiris Kiadó.

Németh L. (2014). Hová jutott a szociális szakma a rendszerváltástól napjainkig? Esély, 26(3), 95-99.

Nyers Sz. (2018). Vissza a jövőbe: Egy pécsi settlement típusú közösségi házból indult önkéntes mozgalom története. Parola, 29(2), 18-22.

Olson, J. J. (2007). Social work's professional and social justice projects: Discourses in conflict. Journal of Progressive Human Services, 18(1), 45-69.

Palinkas, L. A., Horwitz, S. M., Green, C. A., Wisdom, J. P., Duan, N. \& Hoagwood, K. (2015). Purposeful sampling for qualitative data collection and analysis in mixed method implementation research. Administration and Policy in Mental Health, 42(5), 533-544.

Patyán, L. (2015). Characteristics of social work in Hungary: Current and past discussions, and issues concerning to the professionalisation, institutionalisation and the role of social work. In K. Levická \& P. Patyi (Eds.), Res Socialis 2015 Premeny Sociálnej Premeny Sociálnej Práche Hl'adanie Identity Profesie: Zborník príspevkov z konferencie (pp. 129-134). Trnava: Trnavská Univerzita.

https://www.researchgate.net/publication/311761830_CHARACTERISTICS_OF_SOCIAL_

WORK_IN_HUNGARY_Current_and_past_discussions_and_issues_concerning_to_the_prof essionalisation_institutionalisation_and_the_role_of_social_work_ISBN_978-80-_8082-939-

_1 (Letöltés: 2019. 09. 01.)

Paul, R. \& Elder, L. (2006). The miniature guide to critical thinking: Concepts and tools. Tomales, CA: The Foundation for Critical Thinking. https://www.criticalthinking.org/files/Concepts_Tools.pdf (Letöltés: 2017. 07. 16.)

Payne, M. (2014). European social works and their identities. ERIS Web Journal, 5(2), 2-14. http://periodika.osu.cz/eris/dok/2014-02/1-payne-european-social-work-and-theiridentities.pdf (Letöltés: 2019. 01. 20.)

Pik K. (1998). A szociális munka története Magyarországon: A pesti és budai Jóltévő Asszonyi Egyesület. Esély, 10(2), 80-90.

Rácz J. (szerk.) (2001). Devianciák: Bevezetés a devianciák szociológiájába: Szabálykövet(el)ők és bajkeverők. Budapest: Új Mandátum Kiadó.

Reynolds, M. (2014). Equity-focused developmental evaluation using critical system thinking. Evaluation, 20(1), 75-95.

Rubin, A. \& Babbie, E. (2007). Essential research methods for social work. Belmont, CA: Thomson Brooks/Cole.

Sacks, H. (1993) (Ed. Jefferson, G.). Lectures on conversation. Oxford: Blackwell.

Saleebey, D. (2006). Introduction: Power in people. In D. Saleebey (Ed.), The strength perspective in social work practice (pp. 1-24). Boston: Pearson.

Sik D. \& Szécsi J. (2015). A fókuszcsoport mint módszer szerepe a szociális munkában. Kapocs, 14(1) [64], 80-89.

http://tudastar.menedek.hu/sites/default/files/sik-dorka-szecsi-judit_a-fokuszcsoport-mintmodszer-szerepe-a-szocialis-munkaban.pdf (Letöltés: 2019. 05. 10.) 
Singleton, S. (2014). Embracing the social work profession, not the over professionalization. http://news.streetroots.org/2014/02/01/embracing-social-work-profession-not-overprofessionalization (Letöltés: 2019. 01. 23.)

Szabó L. (2017). Szociális munkások a terápiák világában. Párbeszéd, 4(2). http://parbeszed.lib.unideb.hu/file/2/596367dc68d4d/szerzo/Szabo_Lajos_Szocialis_munkaso k.pdf (Letöltés: 2019. 06. 30.)

Szoboszlai K. \& Patyán L. (2016). Esettanulmány a szociális munkában. Párbeszéd, 3(2), 15-28.

Szöllösi G. (2012). A társadalmi problémák konstrukcionista elméletének alapjai. Miskolc: Z-Press Kiadó.

Szöllősi G. (2015). A szociális munka új, 2014-es globális definíciója. Párbeszéd, 2(1). http://parbeszed.lib.unideb.hu/megjelent/html/55192b603fedc (Letöltés: 2017. 06. 17.)

Temesváry Zs. (2018). A szociális munka és a szociálpedagógia modern elméletei. Budapest: L'Harmattan Kiadó.

Udvari K. (2011). Kapcsolathálózati megközelítés a szociális munkában. Esély, 23(5), 100-117.

van Dijk, T. A. (2006). Discourse and manipulation. Discourse \& Society, 17(3), 359-383.

Útmutató a szociális diagnózis elkészitéséhez (2019). http://tamogatoweb.hu/letoltes2019/2019_szocdiag_utmutato.pdf (Letöltés: 2020. 05. 13.)

Weiss, C. (1993). Where politics and evaluation research meet. Evaluation Practice, 17(1), 93-106.

Weiss-Gal, I. \& Welbourne, P. (2008). The professionalisation of social work: A cross-national exploration. International Journal of Social Welfare, 17(4), 281-290.

Wenger, E. (2004). Knowledge management as doughnut: Shaping your knowledge strategy through communities of practice. Ivey Business Journal, 68(3), 1-8.

Yan, M. C. \& Tsang, A. K. T. (2007). A snapshot on the development of social work education in China: A Delphi study. Social Work Education, 24(8), 883-901. doi:10.1080/02615470500342314 (Letöltés: 2020. 05. 13.) 